\title{
家禽経営研究の動向と課題 (2)
}

\author{
杉山道雄 \\ 岐阜大学農学部 岐阜市柳戸 1-1，501-11
}

\section{1.はじめに}

昭和 49 年の石油危機までの家禽経営研究1) に続いて, 昭和 50 年代と 60 年代前半 (1986) の動向と課題につい て検討することが本論の課題である。

とはいえ，日本の養鶏業に欠かすことのできない理論 として評価されるものはとりあげなければならない。

養鶏経営研究者には, 養鶏を題材としながら, 農業経 済理論の実証なり検討をするタイプと, 養鵎経営なり養 鶏業界之密接に関連を保ち乍ら, 実用的研究をすすめる タイプとに分かれる。

前者のタイプは，養鶏業がその特質から，早くから， 商業的農業として展開し, 競争構造を実現させているこ と ${ }^{2)}$ から, 経済現象を検証したり，考察したりするのに 好個の分野であるためである。

後者のタイプは, 養鷄経営が, 土地非依存型の代表的 な部門であり, 早くから展開していること, 又, 産業が 分化していることなどから，行政指導面むさることなが ら養舀界をリードする諸関連部門（ふ卵，飼料，“畜薬な ど）からの指導, 普及関連事業が多いのに支えられてい る。

それらは, ふ卵業や飼料商, 農協, 総合商社, 大雛育 成業, 採卵経営者そのもの, さらに業界雑誌, コンサル タント会社, 各種鵎関連会社, 飼料会社の雑誌等は枚挙 にいとまがない。

こうした発行物の中にも貴重な経営理念が流れており， それらが日本の養鷄経営の代表的流れを形成しているこ とも確かである。

前者の流れをくむ研究は多く各々の学会誌に掲載され， 農業経営経済学の重要な理論を構築していることは, 疑 う余地がない。

後者の流れの研究は, 多くは業界誌に発表され, 実際 昭和 62 年 5 月 28 日受付

Trend and Problems on Poultry Management Study in Japan-a Review- (2)

Michio Sugryama, Dept. of Poultry and Animal Sciences, Gifu University, Yanagido 1-1, Gifu 501-11
に役立つ研究であり，かつ重要な視点や理論を提示して きている。

にもかかわらずこの経済研究と業界誌での研究が，そ れぞれ別の流れであり，お互いに交流することも少なく， 過ぎてきているきらいがある。

前者の研究は, 養鵎業のみでなく, 肉牛, 酪農や水稲, 野菜など幅広く検討され，広い視野から養鵎業に役立っ ていること,これ，一般的, 間接的である。したがって, 実態認識の甘さがあることも事実であろう。

後者の研究は, 養鷄産業の部分的, 直接的ではあるが, 広く，考察されるにしても，部分的，直接的である。そ れだけに理論性に欠け，短絡的でもある。

これらの両研究の潮流は，相互に交流されなければな らない。すなわち, 前者の研究はより, 後者の研究を, 後者の研究はより, 前者の研究をとり入れなければなら ない。すなわち, 方法研究と対象研究の統合である。

この点では, 諸外国ではかなりの点で統合されている ように感じられる。

本稿は, できる限り前者や後者の研究をとりあげ, 過 去 12 年間の研究動向をとりあげ，その課題を整理しょ うとするものである。

しかし, その問題は極めて多岐に亘っているので, 養 鷄経営研究の課題を以下のように整理し，その動向と課 題を検討してみよう。

（1）全般的方向性に関する議論

(2) インテグレーションの構造

(3) ブロイラーインテグレーション

(4) 鵎卵の需給調整

（5）養鶏生産の経営組織

(6) 採卵経営における規模とコスト

(7) 養鵎関連産業

(8) 外国養鷄研究

(9) 採卵経営分析

(10) 養鷄経営とマーケティング, 及び流通構造

2. 養鷄経営研究の課題別動向と課題

1）全般的方向性に関する議論 
石油危機以降，日本的畜産はどうあるべきかについて の論文が多く出された。山村恵一を代伐とする「日本型

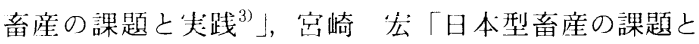

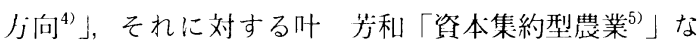
よ゙である。

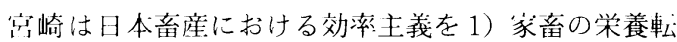
化摔，2）上り低価格な畜産物生産，3）労働生産性の向 上に偏重したことの 3 つをあげている゙”。そしてこの 3 つは濃厚飼料の多給上輸人依仔度の高まりとパラレルに なり，中小笔音比率を $66.4 \%$ と際立って高くなってい る。

この中小家畜への偏重性を次の 5 つにまとめている。 すなわち 1）輸入飼料依仔度の高まり，2）土地からの 離脱性，3）音産贯家の急減とゴールなき規模搪大，4） 品種の外国依你，5）苌外资本の進出によるインテグレ ーション文䣥。こうした結果からの山小家畜経営の到達 点を，(1) 金融の緩和に基づく農協，行政の規模扰大の 推進，(2) 産地価恪に対する生産崱力バー率の低下，(3) 资本の有機的構成の高まり之負債の増大，(4) 産地特化 之流通殞の拢大，(5) 輸入圧下の構造的過剩をあげてい る。

こうしたなかで苌民的音産再建の道として 5 つを提起 している。(1) 経営格差の中で, 技術水準や経営能力の 迎求，(2) 土地利丮に根ざした畜産，(3)苌外资本の民主 的規制之㕮民的畜産，(4) 飼料自給のあら河可能性一 これは稻わら利为，里いを含めた木利州地，国有地の音 産利用，(5)輸人規制之政策の総合的再検討，転換であ $3^{4)}$ 。

定崎の立論の山での山小家畜比摔は緬川羊を入れてい るかどうかが倗だが，むしろ，款物利州家畜（Grain using Animal), 草利为家畜 (Grass using Animal) とすべきだと著者は考える。全世界を鳥瞰する時，イギ リス，オーストラリア，ニュージーランドなど山小家畜

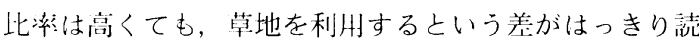
みとれるからである。

もう一つの向性の論点は低コスト化である。鷄卵，

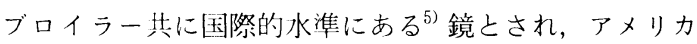
より生産性は高い（1羽当たり）とされているが労働生 库性は，はるかに低いし，コストも高い。又，欧州や大 洋州に比べて俩格は低いとして語価されているが，オラ ンダは低いし，近年は夕イとか台汾で父い。国際競争力 があるというのは，輸出少でなく，国内に海外産物が輸 人された場合，尚生産しうるコストであるという意味 （海外産物の CIF 価格）でのコストである。

もう一つの方向性は商品の差別化であり, 差別的価格 形成の可能性である。周知のとうり日本ではブロイラー
肉屯卵す価格は一つである。フランスでは，上業的鷄肉， 標準鶏，赤ラベル鷄等 3 つが流通消費されている7”。我 国で国際競争力をつけることに差別化論議は少なく，上 記のコスト志向の論議が多( ${ }^{99}$ 。

こうした流れに対してもう1つの流れは，ヨーロッパ での動物福祉論の流れである。

これについてはルース・ハリソン11)，ジム・メイソン 及びピーター・シンガー ${ }^{12)}$ 等の書物が邦訳され，嚴谷 一三男 ${ }^{13)}$ は「動物福祉論の流れとその対応」を述べて いる。

ヨーロッパの動物福祉論の動向は，その法的規制をめ ぐって北欧型とスイス型とに大別されるが，E.C 諸国 内ではケージ 1 羽当たり所要面積, その鶏卵コストへの 波及をめぐって長く議論されてきている

PEDERSEN は豚鵎を「見えざる垡畜 (Invisible Animal)」として, 羊, 乳牛などの放牧家畜 (Visible Animal）に対置させたりしている ${ }^{15)}$ 。しかしこの流れ は日本において，ここではこれ以上追求する必要はない だろう。

2）インテグレーションの構造

インテグレーションの尖態の進行にもかかわらず，そ の諸形態，諸段階の議論はこの 10 年問は殊の外少ない。 これは段階別整理がインテグレーターの種類におくとき, 商業资本・商社资本，その契約，直営化とみるとそこで 総合商社段階という包括的な高度な段階に到達してしま うからである。そのため，商社の主体，形態，機能など 具体的に樑める必要があろう。

また㕮協型は鷄卵が多く，商社型はブロイラーが多い と規定しても，その内部構造を分析しなければならない し，最近 10 年間は大幅に変化しているとみなければな らない。

この点は，インテグレーションの深化を論ずる場合, (1)いわゆる替約型 (Open Account 型) (2) 委託型 (Contract 型) (3)リース型, (4) 所有型, とした区分が 间, 有用だ之みなければならない16)。さらに, (5) 多国 籍型として Congromerate Integration から Multinational Integration への変化を検討する必要がある。

例えばブロイラー, インテグレーションを例にとれば, 40 年代の国内のみの地域間競争から，50 年代はそれに 加えて外国産地之の競争が入り，競争は地域間競争から 企業閌競争へと変化している ${ }^{17)}$ 。

このことはアメリカを例にとれば一層明白で，1960 年代にブロイラーは企業別ランクを揭げ, 上位 50 社の 順位を発表し，州別ランクは形ばかりとなった ${ }^{18)}$ 。これ は各々のインテグレーターがいくつかの州にまたがるか らである。又, 1970 年代に入り鷂卵も䛔州別ランクは 
示されはするが，上位 53 社（これで全生産の $52 \%$ 生産） のランクが発表されていることをみても明らかである ${ }^{18)}$ 。

インテグレーションの構造差で鶏卵は直営が多く，ブ ロイラーで契約型が多いのは何かという問題がある ${ }^{19)}$ 。

これを斉藤はインテグレーションの技術構造から明解 に説明している ${ }^{20)}$ 。すなわち，生産者と処理施設との関 係からブロイラーは, 数ケ月に 1 回出荷であるのに対し， 鶏卵は每日出荷であり，後者において必然的に農場型 (Ranch Packing) か連結型（インラインシステム） になるというあのである20)。

鶏卵とブロイラーについて技術形態は異なるとはいえ， 等しく, 深化の度合を進めていることは間違いない。

杉川ははインテグレーターの種類により，飼料商型，ふ 卵場型，鶏卵商型，さらに総合商社型と分け，それぞれ の特質を論じている(1)99)。

山下は契約農業をアメリカの議論から整理し，とくに 整合機能について考察している ${ }^{23)}$ 。

さらに鶏卵についてアメリカ型のコンプレックスか, サテライト万式かの議論は日本型農家養鶏か，大規模養 鶏かの議論とからめて論議が進んだ。

コンプレックス型では土地が㕕く，地価が安いところ で成立しやすい。また G.P までの運賃は安いが病気が 心配である。サテライト方式では，土地が狭い日本でし かも地価が高く得にくい処で，G.P センターまでの運 賃は高いが，同じょうに One Age System を組めば鷄 病対策上有利というすのである。こうした問題はさらに 実態に則して検討する必要があろう。

3）ブロイラーインテグレーション

ブロイラーの産地間移動をいわゆる旧産地から新産地 へと，新産地の中での九州と東北を対比してその克明な 分析を，吉田忠は行なった

旧産地の動向について，桂利夫は但島ブロイラーをと りあげ26)，新津らは東海の農協型インテグレーション ${ }^{27)}$ を，杉山・豊永らは，岐阜県，東濃地方のブロイラーの 動向を調査した ${ }^{28)}$ 。旧産地でのブロイラ一処理場の零細 性，コスト高，流通の不合理性は又，生産者の零細性之 も対応し，新産地加流入する低コストのト体に対して， 次第に競争力を失ない，南九州卜体依存や，海外産依存 拡大型と崩落型の処理場に分化し始めた。

こうした国内の地域間競争は，海外産ブロイラ一輸入 の増大によって競争構造は三元的となり，ブロイラーイ ンテグレーションも変化した ${ }^{29)}$ 。

こうしたなかで, 駒井享はアメリカやヨーロッパのブ ロイラー産業を詳しく観察し，たくさんの論文を発表し た。

第 1 はフランスの赤ラベル鶏の調査であり ${ }^{30)}$, 第 2 は
アメリカのブロイラーの動向 ${ }^{31 / 32)}$ と食鳥検査制度につ いてである。第 3 はアメリカのブロイラー産業における

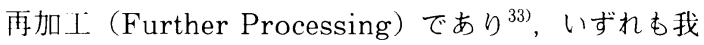
が国ブロイラー産業への示唆に富む提引となっている。

他方, SCHRADER はアメリカのブロイラー産業, 及 びアメリカにおけるブロイラーの流通と価格形成を紹介 している ${ }^{34)}$ 。

価格の決定についていくつかの要因をあげたのち, 「価格の発見」と「価格の報告」を重要視している。そ うした価格の報告に基づいて 3 つの法により值決めが なされる。

商談価格 (Negotiated Price), 算定価格 (Formula Price), 䓌い值 (Price listed) である ${ }^{34)}$

斎藤修はアメリカのブロイラー産業の展開や立地移動 を, 産業形成と南部産地の参入として位置づけ, 産地開 競争の展開，処理場にマーケティングの権限を集中させ る形での展開から，むしろ企業間競争へと展開したこ 之 ${ }^{35)}$, さらにこの競争行動は一層の市場占有率を確保す るため規模拡大, さらに製品差別化をとるインテグレー ターも出現したとその展開の経過を説いた源。これは,

インテグレーションを企業行動やマーケティング論から 接近した最初の成果である。駒井は, ブロイラーの流通 㬰態 ${ }^{37) 38)}$ ，処理場 ${ }^{38)}$, 輸入食鶏 ${ }^{40)}$ などを調査し，ブロイ ラ一産業の全体像を我々に提示している。そして外食産 業や食品産業の研究の重要性が強調され始めた。

海外産ブロイラー輸入の拡大につれて, 夕イのブロイ

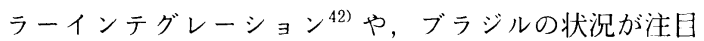
されている(3)。

ブロイラー経営分析の資料は殊の外少ないが，中央畜 産会の診断農家 281 戸を分析して，コスト低下経営の要 因分析を，杉川が行なった ${ }^{44)}$ 。最あ規模の経済性が追求 できる分野として，今後注日されてよい年。

4) 鶏卵の需給調整

昭和 49 年以来, 顕在化した䳕卵過剰傾向は農林水産 省の「鶏卵生産調整に関する通達」に関する指導事業 （56 年以来「計画生産対策」と変更）は, 生産者の要望加 ら始まったのであるが，それに対する無断増羽は絶えな く，現在も進行中である。したがってこれに対する論議 は実際の養鶏家, 行政, 研究者も参加してさまざまな論 点が提示された。

これは国会で何度もとりあげられ，議論されているし， 過剩生産問題の中で最も関心をむたれたものの一つであ る。そのことが, 海外の養鷂産業研究に拍車をかけた。 宮崎宏・兴井倬治・杉川が中心となり，世界各国をとり あげた ${ }^{45)}$ 。れれ 15 ケ国に及んだ46) 61)。

又, ニュージーランドのミッチェルは, 我国の各地で 
同国のエッグマーケティングボードについて講演し，北 海道や東京で大討論会も開催された。

それらの国々の特徵を桜井は E.C 型, アメリカ型, オーストラリア型, カナダ型とした ${ }^{68)}$ 。又, カナダ, 南 ア，オーストラリアをマーケティングボード型，アメリ カのをマーケティングオーダー型とした ${ }^{67) 。}$

マーケティングボード型にはさらに、ニュージーラン ドやイスラエルも含まれるし，E.C 型を国境調整型， アメリカを骞占的需給管理型とした。（これは価格形成 構造からでなく，生産構造が地域的に寡占化しているこ とを指す） ${ }^{62)}$ 。さらに動物福祉型を，北欧型とスイス型 に分けた。北殴型は，ヶージ規制型であり，スイス型は ケージ禁止型である ${ }^{63)}$

問題は日本の計画生産をどのように規定するかであり， 日本型というより法律に基づく tight type でなく, loose type の production control とも呼ばれてい $3^{75)}$ 。

法律に基づく国々があるとはいえ，オーストラリアよ りカナダ，カナダよりニュージーランドの方が規制が多 く，2 万羽を生産権として認可している ${ }^{76)}$ 。

農産物の品目別価格政策は藤谷筑次が要領よくまとめ ている ${ }^{77)}$ 。

それは価格安定対策を市場活用型と市場統制型に分け， 前者を市場介入型之市場不介入型に分けている。市場介 入型を需要調整方式と供給調整方式に分け, 後者はさら に生産調整方式，直接供給調整方式及び間接供給調整方 式に分類した。

鶏卵の訃画生産は生産調整方式に，鶏卵の調整保管は 直接供給調整方式にそれぞれ分類している。これらの農 畜産物価格安定政策手段の分類は，政策手段の考察にあ たって重要であろう。

畜産物の過剩の調整は上記の市場調整（Market Control）のみでは果しえず，次第にさまざまな生産調 整 (Production Control) へ移行し，この二つは各国 で供給管理（Supply Management）として，いくつ かを結合して実施されるようになった。けれども供給管 理下でさえ，供給過剰状態が進行し，需要拡大として消 費拡大対策や販売促進対策など需要増大をも含めて需給 管理（Demand and Supply Management）として 位置づけられている ${ }^{64)}$ 。

それと同時に政策主体も単なる政府にとどまらず，公 社（政府と民間団体）や，産業それ自体に移される場合 あある。

\section{5）養鶏経営と経営組織}

杉山和男は，長年の養鵎組織の分析を通じて「採卵養 鶏発展論」を発表した ${ }^{78)}$ 。これは, 小河原, 東山産業,
児湯養鶏農協の 3 つの採卵生産団地の事例研究を通じて まとめ上げた論文である。

杉山はJ.A. SCHUMPETER の経済発展理論や, E. PENROSE の企業成長論を拠りどころとしながら三つの 事例を詳細に分析しながら生成, 発展, 成熟の過程を叙 述する。ここで成熟過程の次は何が来るのであろうか。 とりあげられた 3 つうち 1 つの事例がその後, 縮小し たように生成, 発展, 成熟の後は老衰, 縮少か, さらに 発展かが真に興味のある課題である。

かつて有名な共同経営が，すぐれた経営分析と評価の のちに解散した事例があったが，事例研究をどう位置づ けるか，それを通して将来を予測することは，我々にと ってむずかしい。

しかしこの中で経営主体や経営行動を基軸に技術革新 をとり入れ，それをすとに生産, 流通, 両面での新展開 をさし示した構図は今迄の家族経営論に対して新しい分 析方法なり，新しい要因をとり入れたものとして評価さ れる。

杉山はさらに発展させて農民型養䳕と企業型養鶏の対 比を試みている。すなわち前者の協同組合組織, 後者の 会社組織, 運営原則における前者の共同原理・奉仕原則, 後者の競争原理・利潤原理である。さらに後者の労務管 理・財務管理が加わり, 経営目標は前者の 1 人当たり所 得の最大化, 後者の資本利回り率の最大化である ${ }^{79)}$ 。

これは筆者がアメリカでの農民養鷄と資本家的養䳕経 営でいくつかは指摘し, 賛成する点が多いのであるが, 杉山和男の農民型養鶏は農協傘下のもののみとして理解 しなければならないだろう。

何故なら，奥田信夫は農家養鶏を販売集約型と専業型 に分けている ${ }^{88)}$ 。販売集約型は, 自家配合を行ない, 自 家販売を行なっている。つまり, 農民型養鶏の経営組織 の特徴は奥田の指摘するような技術条件とも統合して考 察すると尚説得的であろう。

筆者は企業的経営と家族的経営のさまざまな差異の中 から，前者の中にある労務管理（labor management） のあり方がアメリカの事例に照らして, 今後重要となる と考えた ${ }^{82)}$ 。これは 1980 年センサスでみても会社経営 が部門で全経営の $45 \%$ を占め, 養豚経営の $17 \%$, 肉用 牛など $13 \%$, 酪農経営で $7 \%$ などと他の畜産経営に比 しても卓越しているからである。

養鶏産業の性格を述べる見解がいくつか出されている が，例えばマージン率が他の農産物に比し，少ないとか, 製品差別化が困難であるとか指摘されるが，尚，日本的 観察にとよ゙まっていて世界的，歴史的に把える必要があ ろう。

6）養鶏経営における規模とコスト 
規模の経済論は理論上の問題と実際上の問題がある。 多くの場合, 両者が混同されていて混乱が生じている。 又，施設規模と操業規模は分けなければならない。

規模の経済性を考える場合，コストはU字型か L字 型かが問われ，多くの自動車産業の観察によればU字 型とみられるところのコスト上昇段階では操業を停止し, 操短するのが一般的であり, 現実の経営では限りなく L 字型を提するのである ${ }^{89)}$ 。

養䳕経営の実際を考え，規模の経済性を論証しようと する時, 他の条件を均一化することがむずかしい。

例えば，生産面でのコスト低下と購買，販売の取引面 とを分けても尚，自家育雛，自家飼料配合とか自家販売 といった経営形態上の差異を拾象することはむずかし $\left(^{90)}\right.$ 。

さらに地域的条件を同一にして考察することも戸数の 関係で限られてくる ${ }^{90)}$ 。

桜井は実際上を考慮しながら, 吉田六順のいう「主・ 専業の農家養鵎段階におけるU 型曲線の支配, 企業段 階における L 型曲線の可能性, 両者を結んで UL 型コ スト曲線」が現在の日本養鷄を支配する規模法則の現実 とみなしうるとした論理を農水省の生産費調査の分解・ 再集計を通じて, 生産上. 流通上のコストの法則性を検 証しようとした ${ }^{91)}$ 。

その背景には現実に進行している企業的経営の進出と その規模拡大，農家養鵎の再編成が存在しているからで ある。

その後, 杉山・海老沢は現実論ではあるが中央畜産会 での畜産経営診断結果を利用し，低卵価期における採卵 経営の収益分析を行なった であるため，規模の経済性を真正面から解くことは無理 であるが低卵価期には小規模経営で尚，生き残れるのは， 販売上の利点, 経営組織上の利点がある。尚, 高卵価期 での分析が尚必要であるし, 規模の連続性が得られる資 料が必要であろう。

\section{7）養鵎関連産業}

養鵎産業は次第に分化してきており, ひな産業, 飼料, G.P センター, 鶏卵加工などである。これら全養鵎産 業の連携・総計の上に我が国の鶏卵コストが決定される。 それにもかかわらず，今迄，それらを構成するひな 費 ${ }^{100)}{ }^{104)}$, 配合飼料費 ${ }^{94)}$, G.P 費用 ${ }^{96) 105)}$, 流通費用 ${ }^{96)}$ の研究は数えるほどしかない。

それはトータルとしての産業構造の見直しが必要であ るにもかかわらず，情報や資料が少なかったからといえ よう。

例えば，「鶏卵流通統計月報」によれば初生雛価格は 214 円であるが, 台湾とかスリランカ, 又オランダでは
半分以下とされている。これを基に比較すると日本では 高い雚代とされるだろう。

とはいえ，現実の准価格は公示価格より安いとされて いる。

この点は配合飼料価格についてもいえるだろう。同上 月報によれば， $20 \mathrm{~kg}$ 袋入り価格は 1,121 円（1986 年 12 月）でトン当たり 56,050 円となる。けれども現実に は袋での流通量は少ないばかりか，価格むさらに低いも のといわれている。

もしこの表示価格で国際比較を試みるならば，我が国 の配合飼料価格は不当に高い屯のとなる。

こうしたさまざまな条件によって鶏卵なりブロイラー の段階別コストの試算をむずかしくし, 又, 関連諸産業 の分析を困難にしているともいえるだろう。

G.P コストについては農協型 G.P センターについ て，その立地構造と集卵費の構造を調査し，急速に空間 的統一性や技術的統一性及び連携性を証明し，来るべき 養鶏産業の方向を示している。即ち, 分散型 G.P から 団地型 G.P (集中型 G.P) へ, さらに連結型 G.P (インラインシステム) への方向である ${ }^{96)}$ けけれどもこ のインライン型のコンプレックスタイプか, One age system をとるサテライトタイプかは既に論じたところ である。

\section{8）外国養鵎研究}

アメリカないしヨーロッパの養鶏調査は各種の視察団 報告により，我々は生々しい奏態を知ることができ

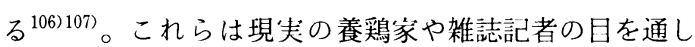
て具体的農場の見聞記であり，H.C. TAYLOR のいう Extensive Survey と呼ぶことができる。

又,こうした国々の農家の Intensive Survey に基つ く調查報告は，米国の各州立大学や試験場によりなされ， 発表され, 又, 米英の養鵎雑誌を通して知ることができ る。

斉藤修の研究はアメリカのブロイラーや鶏卵の産地間 競争をマーケティング論の側面から検討している ${ }^{35) 36) 。 ~}$

Extensive Survey から Intensive Survey へ進む場 合, 又, Theoretical Approarch か又は Secondary data からの Approarch を試みる場合にも前に述べた 理論的研究と対象的研究又は奏際的研究の相互連携なり, 結合又は統一が必要となろう。

周知の如く, 最近 10 年間は, 海外産ブロイラーの輸 入がされ始め，1981年には 17 万トンに達した。円高の 進行むあって，以前からの液卵輸入に加えて「から付き 卵」が中国や台湾から輸入され始めた。

タイからのブロイラー輸入はどのようなものであり， 価格水準はどうかの検討を行なっている。それは単にコ 
ストが安いばかりでなく，先進国（日本など）からの 技術移転を伴いながら，検査体制の確立，需要者に対応 した部分肉, 止肉への加工を通じて合弁型インテグレー

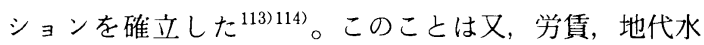
準の低さに加えて円高の進行が益々, 輸入傾向を促進さ せている。

他方, 台湾からの鶏卵輸入は, 試験的とはいえ, 経済 の論理, コストの論理に適うものである ${ }^{115) 116) 。 ~}$

それは単に労賃, 地代の安さばかりでなく, ひなコス

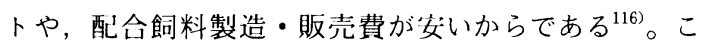
れらは，日本と同じように米国からの種禽・飼料穀物の 輸入であるにもかかわらず，経济合理性を迎求した結果 である。

詳しくは引用した文献に譲るが，こうした NICS と 呼ばれるアジア新興工業国の経済発展と円高の進行を我々 は米欧先進国と同じように注目していかなければならな いことを示している。

その他，スリランカ，バングラディシュのような NICS 以外の諸国では，発展段階的には，はるかに遅れ た構造をもっていて，アジア諸国は一極化しているとい えよう ${ }^{117) 118) 。 ~}$

9) 採卵経営分析

我が国の採卵経営の分析は早くから土地非依存経営之 なったために，「土地面積当たり収益」から解放された。 これはその矛盾を早くから指摘したのであるが, NORMAN がイギリスでこの指標を無意味だといったの は, つい最近の書物である ${ }^{128)}$ 。

けれよ゙も日本の採卵経営分析には古くから奏際上有効 な経営試算（Farm Budgeting）が行なられ，その有 用性が指摘されてきた。

当初は産卵率が重要視されたが, 日産卵量（daily egg out-put）が目標とされ，40 g, $45 \mathrm{~g}^{124)}, 47 \mathrm{~g}^{123)}$, そして今日では $55 \mathrm{~g} \sim 60 \mathrm{~g}$ が追求されるようになった。

この指標を目的としてさまざまな要因を関係づける試 みがなされ，実際にもかなり有用性をむちつづけている。

これは勿論，1人当たり所得を追求する上での一つの 重要な柱として, 飼料要求率や, 更新率, 羽数と共に重 要な要因を構成している。

この 1 羽当たり産卵量や, 飼料要求率はあくまで技術 的指標であるところに日本の特徴がある。その経済的指 標は, 単に卵価×産卵量として屯試算の域を出ないこと となる。

NORMAN は経営指標として 'Margin over purchased feed cost’をつかい, その要因として飼料費 100 ポンド当たり産出高と. 産出高・飼料費比率を用い ている ${ }^{129)}$ 。これは日本的にいえば, 飼料効率と卵飼比
の別の表現であるが異なる点は産出高の中味である。産 出高はもとより卵, 肉, 鶏粪の販売高の合計である。

さらに前述の土地要因が制限要因でなくなったとし， 労働之資本，とりわけ資本要因として，資本収益又は資 本収益率を目標とする ${ }^{129)}$ 。

この点は, Margin 追求，その裏にあるコスト追求 であり，わが国の総量追求と異なる側面をもつのは，わ が国が依然として家族経営を分析の対象においているか らであろう。

さらにアメリカの経営診断の歴史を追求すれば，家族 経営, 企業的経営, 企業経営に行くにつれ, 農業所得, 労働所得, 資本収益率と指標が変わり, 産出高から, コ ストコントロールを併用してからコスト（追求）中心主 義へと変化した様相をみても明らかである ${ }^{132)}$ 。

わが国で努めて産卵量とかの生産管理から購買・販売 管理が重要となり始めたことは，家族経営から企業的経 営にさしかかり，さらにコスト中心主義にさしかかりつ つあるとみてよかろう。

福田勤は資金融資経営の経営診断基準を経営全体費用 の中加淔接的経費率, 飼料費率, 七ナ睡入費率の妥当 性を検討し，採卵鶏所得率の妥当性, 経営当たり労働及 び労働力，借入金利子比率，減価償却費率などを比率分

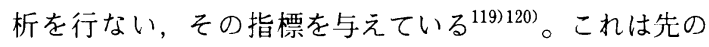
技術指標分析に対して, 経営比率分析であり, 前者の優 劣を踏まえて, 経営総体が検討されている。とりわけ, 資本・施設の導入，借入れなど外部資本の増大傾向の中 で資本収益や資本収益率が重要となり始めたことを示す であろう。

伊藤孝は「畜産経営における自己診断の手順之手法」 の中で経営診断を次のように分けている ${ }^{130)}$ 。すなわち まず，診断の手法は外部比較法と内部比較法に分かれ， さらに外部比較法は標準比較法 (基準比較法), 直接比 較法（経営間比較法）に, 内部比較法は時系列比較法, 計画比較法, 部門間比較法に大別している ${ }^{130)}$ 。

自己診断法として記帳の内容, 程度により, 鶏卵生産 費にも差が生ずるが試算法により，

1. 直接材料費及び雇用労賃のみ計上の場合。

2.上記に期首・期末の鶏の評価を行ない，その増加額 を計上する。

3. 上記 2 に, 建物・施設および機械器具の減価償却費 を計上する。

4. さらに家族労賃, 販売及び一般管理費，事業外費用 を加え，ほぼ鶏卵生産費を算出できるとしている。こ れはさらに 5 段階として地代及び利子を計上し，第二 次生産費の算出に至って始めて, 自己の試算法 （Farm Budgeting）は完成するだろう。 
さらに近年, 養鶏経営分析に対するコンピュータの利 用の進展である。

既に企業経営, 協業, 共同経営では応用されているば

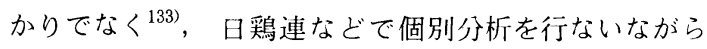
診断を行なっている。

愛知から始まった系統農協の経営診断システムは, 全 農方式とも呼ばれるべき方式(135) 138) 139) で，全国で利用さ れているし, 長年, 中央畜産会が実施してきた畜産コン サルテーション事業はコンピュータ利用による診断とな

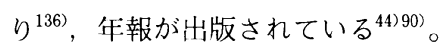

これらは農水省統計情報部の発表する『畜産物生産費 調査』より平均規模が大きいばかりでなく, 各種の分析 に有用である。

コンピュータ利用は, 鶏舍管理, 経営管理, コスト管 理, G.P センター，販売管理など個別に利用されてい

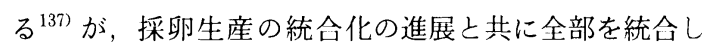
て利用できるようなシステムも必要であろう。

10）養鷄経営とマーケティング及び流通構造

この点については 12 年前の「家禽経営研究の動向と 課題」)においてアメリカの動向を紹介したのであるが, 現実にも 1 羽当たり産卵量の数 $\mathrm{g}$ の追求と同様, $1 \mathrm{~kg}$ 当たり販売卵価を 10 円以上上げることが尚大切なこと が販売戦略として重要であるといわれ始めた。

奥田信夫は既にみたように販売集約型農家養鷄として 専業型の問屋, 農協及び G.P センター出荷のものと区 別した ${ }^{88)}$ 。

杉山らは中小家畜経営のマーケティングにおいて, 養 䳕経営の展開形態に応じてのマーケティングのあり方に ついて述べた ${ }^{140) 1411 。 ~}$

それは，我が国における共販運動が農家手取率を 50 \% 以下から $80 \%$ まで高めたこと，そして，集団養鵎に おける共販, 都市近郊養鵎における販売活動などであ る $^{141142)}$ 。

杉山, 畦上は, $1 \mathrm{~kg}$ 当たり販売卵価に 100 円の開差 のあることに着目し，農家養鶏における販売管理の夕イ プを 4 つに分けた。それは完全販売委託型, 不完全販志 管理型, 不完全販売委託型, 完全販売管理型とし,この 形態の進化につれて 304 円，313 円，322 円，334 円之 卵価が上昇することを分析した。その差は 9 円， 9 円， 12 円と拡大している ${ }^{140)}$ 。

このことは今日多くの都市近郊養鶏家が, 自らの販売 先をさがし乍ら存立していること, 又大規模養䳕家屯販 売管理を追求していることを考えると，重要といわなけ ればならない。

その一環として近年, 鵎卵産直が進行した。有色卵の 小規模平飼型, 大規模平飼型, 及び中規模ヶージ型, 大
規模ヶージ型之同時に大規模放し飼い型もあらわれ，生 協や消費者グループへの産地直結やスーパーへの産地直 送があらわれた ${ }^{146)}$ 。

我が国での鶏卵の農家手取率は $71 \%$ 之国際的に高く， 英仏の $40 \%$ ，アメリカの $60 \%$ など，諸外国ではかなり 低い。これは売上税や流通構造, 加上包装なよ゙が影響し ている ${ }^{147)}$ が，ボード諸国の 70\% を除けば日本の流通費 率の低さは注目されているところである ${ }^{144)}$ 。

鶏卵流通を巡っては近年のアメリカの鶏卵生産の立地 移動である。かつてのアメリカ養鵎の南進化から 1980 年代の北進化の要因の一つに著しい流通費の上昇がある。

この流通構造, 流通機能, 系統農協のあり方を巡って いくつかの成果が発表されている(146) 148)。

特に近年の特街として生産者と消費者の産值活動であ り，日生協などからその具体的取り組みが紹介されてい る $^{151) 152)}$ 。

これはいくつかの流通機能を省略して, 流通費を節約 しながら生産者, 消費者双方に利益をもたらそうとする あのであるが，消費者からの生産に対する要望が出され， それに対して生産費を補償したりしている。他方, 生協 組合員の拡大につれて, 生産をどう対応させるか, 又, 共同講入型から店舗型への生協の形態変化につれてどの ように価格設定を行なうかは課題といえよう。又, 生産 者にとっての余剩卵，不足卵など数量調節をどう行なう かも課題であろう。

\section{3. おわりに}

以上, 養鶏経営経済に関する最近 10 年閒の主な研究 論文や成果を紹介, 検討してきたが 10 年以前の諸成果 に対して，その発表された論文数，著書数む多く，用谷 も多岐に亘り, 又, 深められてきている。

とりわけ, 需給調整論, 経営組織論, 流通論, マーケ ティング論や, 関連産業論, コンピュー夕応用論の新し い成果が生まれている。

益々国際間競争の進行する中で，欧米の養鶏研究と同 時に, アジア諸国，とりわけ NICS の研究も必要とな ろう。

又，そうした中で，トータルとしての鷄卵産業なり， ブロイラー産業のあり方, 価格形成, 調整問題が問われ るであろう。

尚, 海外での養鶏経営経済及びマーケティングについ ては，関連するもののみをとりあげ，他は省略している。

\section{文献}

1）杉||道雄（1975）家禽経営研究の動向と課題, 家 禽会誌， 12 (3)：107-113. 
2）杉山道雄（1984）畜産における商業的農業の今日 的課題一採卵業に抢ける一考察, 農業問題研究 (19) : 12-22.

3）杉山道雄（1983）採卵鶏経営, 畜産経営構造問題 研究会編, 日本型畜産の課題と実践, 明文書房, 41-54.

4）宮崎 宏（1983）効率主義が招く危機的構造一農 政ジャーナリストの会編, 日本畜産の再検討, 農 林統計協会, 68-92.

5）斉藤富士雄（1983）採卵養䳕業一資本集約的農業 の産業的展開に関する調查研究, 国民経済研究協 会, 47-81.

6）宮崎 宏（1984）日本型畜産の方向, 家の光協会, 1-271.

7）杉山道雄（1986）ブロイラー，吉田寛一・宮崎 宏 他編，畜産物の消費と流通機構，農文協，187-192 頁.

8）杉山道雄（1986）食鳥輸入の現状と将来一夕イの 骨なし鶏肉輸入を中心に一音産の研究, 40-1 : 198-204.

9）杉山道雄（1986）畜産経営の展望一中小家畜を中 心に一，農業之経済，10月号，14-21.

10）杉山道雄（1983）日本鶏卵産業の国際競争力之そ の可能性, 畜産の研究, 37-1: 197-202.

11）ルース・ハリソン（橋本明子他訳）（1979）ア二 マリ・マシーン一近代畜産にみる悲劇の主役たち, 講談社, 1-293.

12）ジム・メイソン・ピーター・シンガー（高松 修 訳) (1982) アニマル・ファクトリー, 現代図書, $1-229$.

13）㒈谷一三男（1981）動物福祉論の流れとその対応, 鶏の研究, 654 号 : 105-108.

14) The Danish Branch of W.P.S.A. (1981) First European Symposium of Poultry Welfare, 1-238.

15) Andersen, A. (1984) Legislation affecting the Economic Results of Broiler and Egg Laying Farms. Proceedings and Abstracts of 17 WPSA Congress. 79-83.

16）杉川道雄（1973）インテグレーションの構造的特 質, 農業経営発展の理論, 養賢堂, 337-360.

17）杉山道雄（1986）中小家畜経営の展望，農業と経 済，10月号，14-21.

18） Broiler Industry 及び Poultry Tribune 誌.

19) Rogers, C.B. (1979) Poultry - "Another Revolution in U.S. Farming”, U.S.D.A., 148-189.

20）斉藤 修（1987）アメリカ鶏卵産業におけるイン テグレーションの展開と競争構造の变化, 農業経 営研究. 25-1. 46〜 55.

21) Sugiyama, M. (1984) Economic Considerations of Poultry Industry in Japan, $\cdots$ Case Studies on Integrated Egg Production, W. P.S.A. Proceedings and Abstracts.
22）宮崎 厷（1982）農業インテグレーションの奏態 上展望, ジュリスト総合特集, 日本の食糧, 風土, 農政, 食文化, No. 28, 92-102.

23）山下雄三（1983）契約農業と整合機能，筑波大農 林社会研究, 2 号, 22-24.

24）杉山道雄（1986）養䳕産業における技術革新と経 営变革, 農林業問題研究, $22(8): 18-26$.

25）吉田 忠（1983）ブロイラーの産地間競争とその 規定要因，農業計算学研究 $16: 35-47$.

26）桂 利夫（1980）但馬地方におけるブロイラー産 業とインテグレーション, 農業計算研究 $13: 83-$ 93.

27）杉山道雄（1979）ブロイラーインテグレーション の経済的研究, 農林経済研究 $5: 37-64$.

28）杉山道雄（1983）ブロイラーインテグレーション の経済的研究 (11), 岐皁大畜経資料 22:1-46.

29）杉山道雄 : 前掲「畜産経営の展望」14 21.

30）駒井 亨（1984）E.Cにおける家禽産業と豚肉 産業の実態一フランス，オランダ，デンマークの 実態, 海外畜産物市場動向調查報告書, 全国農協 中央会, 5-146.

31）駒井 亨（1985）アメリカのブロイラー産業の動 向, 前掲, 海外農産物市場調査報告, 59-152.

32） SCHRADER, アメリカのブロイラー産業, ブロイ ラ一産業研究所, 1-12.

33）CUnningham, F.E. (駒井訳) :「アメリカにお ける家禽肉の加工・利用」ブロイラー産業研究所, 31-52.

34） SCHRADER, アメリカにおけるブロイラーの流通 と価格形成, ブロイラー産業研究所, 1-28.

35）斉藤 修（1984）アメリカにおけるブロイラー産 業の展開と立地移動, 産地の形成之南部の参入及 びインテグレーションと産地間競争, 広島大紀要 $23: 25-53$, 及び 55-83.

36）斉藤 修（1986）アメリカにおけるブロイラー産 業の展開と寡占的競争構造の成立（1），農産物市 場研究 $22: 31-41$.

37）駒井 亨（1976）ブロイラー流通実態調查報告書, 畜産振與事業団. 1 98.

38）駒井 亨（1978）食鷄処理場実態調查報告書, 同 上. $1 \sim 66$.

39）駒井 亨（1985）食鳥の流通改善調査事業調査報 告書, 日本食鳥協会. 1 26.

40）駒井 亨（1980）輸入食鷂の流通実態調査報告書, 畜産振興事業団. 1〜143.

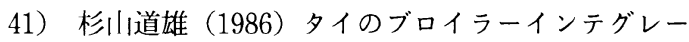
ション, 養鶏時報, 39(1): 29-32.

42）杉山道雄（1985）タイのブロイラーインテグレー ション, 海外畜産物調査報告, 111-152.

43）杉山道雄（1986）ブロイラー，畜産物の消費と流 通構造, 農文協, 187-192.

44）杉い道雄（1987）ブロイラ一収益と生産原価の構 造, 経営診断からみた畜産経営 (1987 年報), 中 央畜産会. $131 \sim 151$. 
45）宮崎 宏・桜井倬治・杉川道雄（1981）諸外国の 鶏卵対策調查報告書，全国鶏卵価格安定基金.

46）宮崎 宏・桜井倬治・杉川道雄（1981）E.C，同 上, 107-137.

47）桜井倬治（1981）アメリカ，同上，1-70.

48）桜井倬治・杉山道雄（1981）イギリス, 同上, 139-172.

49）桜井倬治・杉川道雄（1981）オランダ, 同上, 173-182.

50）宮崎宏・杉川道雄（1981）西ドイッ，同上, 183-208.

51）宮崎 宏・桜井倬治・杉山道雄（1981）フランス, 同上, 209-218.

52）宮崎 宏（1981）オーストラリア，同上，257-298

53）桜井倬治（1981）南アフリカ共和国，同上，315328.

54）杉川道雄（1981）カナダ，宮崎 宏他：諸外国の 鶏卵対策調查報告書，全国鶏卵価格安定基金，71106.

55）杉山道雄（1981）デンマーク，同上，219-226.

56）杉川道雄（1981）ノールウェ一，同上，227-234.

57）杉山道雄（1981）スウェーデン，同上，235-242.

58）杉山道雄（1981）フィンランド，同上，243-250.

59）杉山道雄（1981）スイス，同上，251-256.

60）杉山道雄（1981）ニュージーランド，同上，299313.

61）杉山道雄（1981）イスラエル，同上，329-339.

62）杉山道雄（1982）諸外国の鶏卵需給管理方式の類 型と現状, 畜産コンサルタント，6月号， 26-33.

63）杉山道雄（1982）動物福祉型および北欧型, 桜井 他 : 鶏卵の需給調整に関する理論的・実証的調查 研究, 農業開発研修センター, 3 月号, 100-115.

64）杉山道雄（1983）鶏卵生産調整における農協の役 割, 協同組合奖励研究報告, 第 9 輯, 335-356.

65）杉山道雄（1980）鶏卵の過㮃問題之養䳕の方向, 畜産物の過剩問題と畜産経営の力向, 農業技術研 究所, 5-15.

66）桜井倬治（1983）鶏卵需給調整対策の現状と課題, 農業と経済, 4月号, 60-65.

67）桜井倬治（1979）「卵価安定制度運用の現状と課 題」同上，8月号，12-21.

68）桜井偵治（1981）鶏卵需給調整をめぐるマーケテ ィング・オーダーとマーケティングボード，東井 正美編：現代日本農業経済論，富民協会，215246.

69）桜井倬治（1976）鵎卵市場隔離の経済効果に関す る研究, 畜産振興事業団, 1-156.

70）桜井倬治（1977，1978，1980）鶏卵の需給構造に 関する研究（I ），（II ），（III）, 畜産振興事業団, $1-135,1-116,1-130$.

71）宮崎 宏（1981）鵎卵の需給構造之調整対策の課 題, 暒井 功編：農産物過剩，179-207

72）宮崎 宏（1981）養鶏経営面からみた需給調整と これからの課題, 畜産コンサルタント，1月号，
248.

73）中西久一（1985）卵の需給, 浅野悠輔・石原良三 編著: 卵一その化学と加工技術, 光琳，1-49.

74）ビル・ミッチェル（1981）エッグボード講演会資 料, 全国養鵎経営者会議, 1-14.

75) Poultry international: Poultry International Japan File, vol. 24-3, 1985, 3 月号, 12-45.

76）杉川道雄（1984）鵎卵の過剩と需給調整，土屋圭 造編 : 農産物の過剩と需給調整, 農林統計協会, 189-210.

77）藤谷筑次（1976）卵価安定政策の理論的検討, 鶏 卵市場隔離の経済効果に関する調査研究, 畜産振 興事業寺, 22-34.

78）杉山和男（1981）採卵養鵎経営論, 明文書房, 1212.

79）杉山和男（1981）家族経営と企業経営の比較考察, 農業之経斎，3月号，14-21.

80）杉和男（1983）近郊養鶏経営発展のメカニズム, 農林業問題研究, 70 号, 37-42.

81）杉山和男（1986）採卵養鶏における技術变革と経 済変革, 農林業問題研究, 84 号, 22-30.

82）杉山道雄（1985）企業的経営の規模拡大と労働力 問題一いわゆる労働管理 (学) の出現亡位置づけ について，農業と経済，8月号，39-47.

83）杉山道雄（1984）採卵鶏経営の特質, 島津 证編 : 畜産経営学, 187-199, 文永堂.

84）杉川道雄（1983）鶏の経営的性格，川極栄司編： 農業経営改善ハンドブック, 全国農業改良普及協 会. 985 987.

85）杉川道雄 - 鶴見昇三（1983）採卵鶏，同上，10601079.

86）斉藤 勝: 養鶏産業の現状と今後の展望，25-31.

87）桜井倬治: 採卵鵎飼養の経営革新, 菊地泰次編 : 農業経営の革新, 323-338.

88）奥田信夫（1979）鵎卵生産の展開之農家養鶏, 明 治大学農学部研究報告, $45: 23-42$.

89）越後和典（1969）規模の経済性，新評論社，1-192.

90）杉山道雄・海老沢昭一（1986）低卵価期におりる 採卵経営の収益分析, 経営診断からみた畜産経営, 中央畜産会. 109 136.

91）桜井倬治（1982）採卵養鶏の規模の経済性を考え る，農業之経済，56-64.

92）山本康貴・黒柳俊雄（1986）鵎卵の生産性向上に 関する計量分析, 1964-83, 農経論叢, 42 .

93）桜井倬治・吉田 忠・杉山道雄・杉山和男 早川 治（1980）わが国採卵養鶏の立地移動, 経 営規模, 経営組織の構造的変化に関する調査研究, $1-180$.

94）伊藤紘一（1980）飼料産業と日本畜産の課題, 農 業之経済, 12 月号, 30-36.

95）岡崎 周（1975）養鵎家からみた飼料問題, 長期 金融, 49 号, 53-59.

96）杉山道雄（1985）鶏卵 G.P. センターの立地構 
造とコスト，家离会誌，22-6:311-322.

97）桜井倬治（1982）鶏卵，高橋伊一郎編：輸入農産 物一輸入制度と国内流通，お余の水書房，273298.

98）芦田齐三（1985）液卵戦争，鷄卵肉情報センタ一, $1-288$.

99）杉山道雄（1986）養鵎産業における技術革新と経 営変革, 農林業問題研究, (83), 45-53.

100）杉山道雄・畦上光弘（1985）農協型 G.P. セン 夕一の販売管理, 岐阜大農研報, 50, 409-421.

101）杉山道雄（1984）ふ卵場から養鶏インテグレーシ ョンへ発展, 農業経営大事典 (1), 学習研究社, 148-149.

102）液卵公社（1977）国内液卵の生産流通実態調查報 告, 畜産振興事業団, 1-201.

103) Sugiyama, M. (1986) Economic Considerations of Egg Industry in Japan, 1986. OASERD. 1-23.

104）杉山道雄（1983）外国産鵎が日本養鵎業に与えた 影響，農業之経済，49-5，5月号，57-63.

105）桜井倬治・杉山道雄・中西久二他（1981）G.P. センターを中心とした鷄卵の流通実態調査報告書, 畜産振興事業団, 1-215.

106）杉浦嘉明（1987）ヨーロッパの養鶏事情視察報告 （1）～(7), 鷄卵肉情報.

107）同（1987）アメリカの養鶏産業視察報告 (1), 同上.

108) Poultry Tribune, Poultry World, Poultry International. など.

109）小川総夫（1985）最近のオランダ養鵎, 養鶏経営 者, 128 号, 1-12.

110）梅原宏保（1981）エッグボードの歷史と役割, 養 鵎経営者, 101 号, 1-34.

111）辻純三郎・杉山道雄・千田正作（1984）アメリカ における鶏卵生産, 流通構造と価格形成, 農林経 済研究，(9)，31-51.

112）杉山道雄（1979）欧米畜産事情, 世界の養鶏経営, 日本経済評論社, 1-198.

113）杉山道雄（1986）タイのブロイラー産業の特徵に ついて, 家离会誌, 23(1):37-42.

114）杉山道雄（1986）タイのブロイラーインテグレー ション, 家禽会誌, $23(2):$ 108-117.

115）杉山道雄（1987）台湾養舀業の経済的研究, 家禽 会誌, 24(1)：50-57.

116）杉山道雄（1987）台湾における飼料産業の構造, 家禽会誌, 24(1)：58～64.

117）杉川道雄（1984）東南アジアにおける舀卵の需給 と流通構造一スリランカ, バングラディシュ及び ホンコンについて, 海外畜産物市場動向調查報告 （2），全国農協中央会，147-224.

118）宮崎 宏・駒井 享・杉山道雄（1983）海外畜産 物市場動向調查 (1), タイ, フィリッピン, 全国 農協中央会, 1-300.

119）福田 勤：採卵鶏経営, 農業経営総合改善計画評
価の手引（1）, 農林漁業金融公庫， 1-79.

120）福田 勤：ブロイラー経営, 同上（1), 同上, 146.

121）木村唯一（1981）養鵎ポケットブック，日本養鷄 協会, 1-400.

122）田先威和夫 - 山田行雄 - 森田琢磨 - 田中克英 （1982）養鷄ハンドブック，養賢堂，479-537.

123）全国愛農会, 経営技術部（1970）愛農養鵎十大原 則 $47 \mathrm{~g}$ 定量採卵法, 全国愛農会本部, 1-330.

124）後藤静一編（1967） $45 \mathrm{~g}$ 定量採卵養鷄法, 富民 協会, 1-259.

125）後藤静一（1963）ゴトウ養鵎基礎講座，後藤ふ卵 場, 1-242.

126）遠藤国雄：採卵養鶏の経営分析と対策，茨城鶏試 採卵養鵎調查資料 20 年史. $1 \sim 55$.

127）杉山道雄（1986）経営診断からみた最近の採卵養 鶏, 畜産コンサルタント, 11 月号, No. 263, 3642.

128）杉原健一（1987）経営分析からみた鷄卵生産費之 今後の養䳕経営について, 日鵎時報, 106 号.

129） Norman, L. 他（1985） The Farm Business 2nd Edition p. 217.

130）伊藤 孝（1977）畜産経営における自己診断の手 順之手法（採卵鵴），中央畜産会，213-267.

131）太田 澄（1977）最新商的養鷄簿記, 鶏友社, 1155 .

132）杉山道雄（1973）アメリカにおける養鶏経営診断 （1），岐阜大農研報，34，391-411.

133）西川・木村（1978）マイクロコンピュー夕の養鶏 および鵎卵管理システムへの応用に関する調查研 究, 日本情報処理開発協会, 1-240.

134）藤田儀助（1982）リースコンピュータによる養鷄 経営のコストダウン，長期金融，60 号，53-73.

135）新井 肇（1982）系統農協による畜産経営診断シ ステム, 同上, 114-125.

136）栗原幸一：畜産経営診断におけるコンピュー夕利 用一中畜診断システムの概要と運用について一, 同上, $126-133$.

137）瀬良英介他（1983）畜産用コンピュータの実際と 応用, 鶏卵肉情報センター, 1-351.

138）沼田正弘（1978）電算機による採卵鶏経営診断シ ステム, 全農畜産中央研究所, 1-225.

139）全農畜産生産部（1981）コンピュータによる採卵 鶏経営診断システムの手引, 全農, 1-182.

140）杉山道雄 - 畦上光弘（1985）採卵養鷄経営の販売 管理に関する研究, 岐阜大農研報, 50 : 391-407.

141）杉山道雄（1986）中小家畜経営とマーケティング, 菊元富雄編：農業経営とマーケティング, 農業経 営学講座, 8, 地球社, 117-138.

142) Sugiyama, M. (1986) Performance of Cooperative Marketing vis-a-vis Private Traders, Seminar of Marketing Farm Products, March, 1986. A.P.O. 1-25.

143) Sugiyama, M. (1986) Physical Distribution 
of Farm Products: Examples of Chicken Meat, Eggs and Beef Cattle in Japan, Seminar of Marketing Farm Products, A. P.O. 1-25.

144) Sugiyama, M. (1987) Japan's Cooperative have Improved Producers' Returns, Poultry International, 46-48.

145）杉川道雄（1981）オーストラリア，ニュージーラ ンド及びイスラエルにおける鶏卵消費拡大対策, 鶏卵肉情報 1月号, 36-47.

146）杉川道雄（1986）鶏卵の流通機構，吉田寛一他編 : 畜産物の消費之流通機構, 農文協, 308-346.

147) RichaRDSON, D.I.S (1987)Producer/Retail
Marketing Margin Price Spreads, 19821986, I.E.C., 1-5.

148）高橋伊一郎（1980）農産物市場論，明文書房，1213.

149）生田行雄（1981）農産物流通論入門・総論，全国 協同出版, 1-208.

150）生田行雄（1981）農産物流通論入門・各論, 全国 協同出版, 1-194.

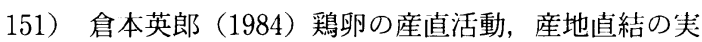
践, 時潮社, p. 181-191.

152）日生協（1984）産直一生協の実践，日本生活協同 組合連合会. 1 452. 